\title{
Venezuela, Bolivarian Republic of
}

National Cancer Institute

\section{Source}

National Cancer Institute. Venezuela, Bolivarian Republic of. NCI Thesaurus. Code

C17250.

A country in northern South America, bordering the Caribbean Sea and the North Atlantic Ocean, between Colombia and Guyana. 